Int. J. Environ. Sci. Tech.

(C) Spring 2006, Vol. 3, No. 2, pp. 131-139

\title{
Lead remediation of contaminated water using Moringa Stenopetala and Moringa oleifera seed powder
}

\author{
L. M. Mataka, ${ }^{*}$ E. M. T. Henry, W. R. L. Masamba and S. M. Sajidu \\ Chemistry Department, Chancellor College, University of Malawi, Zomba, Malawi
}

Received 29 October 2005;

revised 7 March 2006;

accepted 23 March 2006;

available online 20 April 2006

\begin{abstract}
The increasing influx of heavy metals into water bodies from industrial, agricultural, and domestic activities is of global concern because of their well documented negative effects on human and ecosystem health. A recent study of streams in Blantyre and Zomba, Malawi revealed lead levels of up $0.118 \mathrm{mg} / \mathrm{L}$, exceeding the World Health Organisation acceptable level of $0.01 \mathrm{mg} / \mathrm{L}$. Our ongoing study on low cost effective heavy metal remediation techniques in developing countries has already demonstrated that Moringa oleifera, the well known source of natural water clarifiers, is effective in heavy metal detoxification of water. This paper presents the first reported use of a related species, the African moringa, Moringa stenopetala for lead detoxification and preliminary investigation of the interaction of the metal with the polyelectrolytes of $M$. oleifera and stenopetala. The potential of $M$. stenopetala for lead removal was tested by means of jar tests. With an initial lead concentration of $7 \mathrm{ppm}, M$. stenopetala seed powder, at doses of $0.50,1.00,1.50,2.00$ and $2.50 \mathrm{~g} / 100 \mathrm{~mL}$, reduced the concentration of lead by $20.00 \pm 0.00,46.19 \pm 2.06$, $71.19 \pm 2.06$ and $89.43 \pm 0.60$ and $96.23 \pm 0.12 \%$ respectively. $M$. stenopetala was more effective than M. oleifera in removing lead from water ( $\mathrm{p}=0.001$ at $95 \%$ confidence level). For oleifera, lead levels decreased exponentially during the first $5 \mathrm{~h}$. of the reaction and then equilibrium was established; for stenopetala, a linear decrease was observed. The $\mathrm{pH}$ of the mixture rose from 2.30 to a maximum of 2.53 and 2.57 and then fell to an equilibrium value of 2.30 and 2.29 for oleifera and stenopetala respectively. Lead removal was also affected by $\mathrm{pH}$, ionic strength, and water hardness. Our results show that $M$. stenopetala has potential in lead remediation of contaminated waters. Further studies are being carried out on remediation of other metals and the mechanism of the metal moringa interaction.
\end{abstract}

Key words: Lead, Moringa oleifera, Moringa stenopetala, heavy metals, water pollution, remediation.

*Corresponding Author, E-mail:emhenry@chanco.unima.mw

\section{INTRODUCTION}

The United Nations Environment Programme's (2004) Water Policy and Strategy identifies several water focal areas including fresh water scarcity, land based pollution sources, aquatic biological diversity, resource use and management, and knowledge and technology transfer in integrated water management. The Malawi State of the Environment Report notes that water degradation is a major environmental problem that threatens the health and well being of humans and ecosystems (Malawi Government, 2002). Improper disposal of various types of waste, deforestation, and poor agricultural practices that encourage soil erosion and deposition of sediments into the water bodies were identified as the major causes of water degradation in Malawi. Studies of Malawian urban water bodies and wastewater treatment plants revealed that some water quality parameters including heavy metals exceed the World Health Organization (WHO, 2004) acceptable limits (Matope, 2002; Banda et al., 2001 and Sajidu et al., 2005). Of particular concern are the high levels of lead in some of the water bodies. The Sanitation Master Plan for the City of Blantyre (Matope, 2002) reported lead levels of 0.73-0.96 mg/L in Mudi and Limbe streams and Banda et al., (2001) recorded $0.23 \pm 0.00 \mathrm{mg} / \mathrm{L}$ lead for the Lunyangwa river basin, all above the WHO acceptable limits of less than $0.01 \mathrm{mg} / \mathrm{L}$. Our recent quality inventory compilation of Blantyre streams (Limbe, Nasolo, and Mudi) and wastewater treatment plants (Limbe and Soche) recorded levels of lead from 0.027 to $0.118 \mathrm{mg} / \mathrm{L}$ with most values exceeding the WHO limit (Sajidu et al., 2005). Lead is a pollutant of global concern with well known toxic effects (Alloway and Ayres, 1990). Major sources of lead pollution in water are lead-acid batteries, lead pipes, solders, agricultural chemicals, lead mining, and vehicle exhausts especially where, as in Malawi, leaded petrol 
has not been completely phased out. Lead is a powerful neurotoxin and a range of pathological conditions is associated with acute lead poisoning, the most characteristic being cerebral oedema. Clean-up technologies for the removal of lead and other heavy metals from water include chemical coagulation using aluminium and ferric salts (Fatoki and Ogunfowokan, 2002) and cationic surfactants (Evans, 2003); physical precipitation using ion exchange and adsorption (Singh et al., 2001) and phytoremediation that includes rhizofiltration, phytostabilisation, phytoextraction (Lyte et al., 1998 and Lambert et al., 2003). However, water and wastewater treatment in Malawi does not include heavy metal removal or monitoring due to the high costs and/or the lack of technical expertise. Recently there has been increased interest in the subject of natural coagulants for treatment of water and wastewater in developing countries (Jahn, 1986; Ndabingesere et al., 1995; Sutherland et al., 1994; Gebremichael, 2004 and Henry et al., 2004). The tropical plants of the family of Moringaceae are amongst some of the natural coagulants that have been studied for clarification of turbid water. Moringa oleifera is the most widely distributed, well-known and studied species of the family Moringaceae because of its previous economic importance as a source of the commercially important 'Ben oil' and more recently, as a multipurpose tree for arid lands and a source of water purifying agents for developing countries (Morton, 1991). M. oleifera is native to sub-Himalayan Northwestern India and Pakistan but the plant was distributed to other areas of tropical Asia in prehistoric times and to other parts of the world including Malawi during the British colonial era. M. stenopetala, often referred to as the African Moringa Tree, originates from southern Ethiopia and Kenya (Jahn, 1991). The food, fodder, water clarifying and medicinal uses of the Moringaceae, especially oleifera are well documented and the trees are recommended for live fencing, intercropping, and pollution control (Morton, 1991; Moges, 2004; Coote et al., 1997; Pratt et al., 2002; Williamson, 1975; Palgrave, 1983 and van Wyk and van Wyk, 1997). The water soluble Moringa seed proteins possess coagulating properties similar to those of alum and synthetic cationic polymers. Jahn (1981) first studied and confirmed the coagulating properties of Moringa seeds after observing women in Sudan use the seeds to clarify the turbid Nile waters. The active agents in Moringa extracts responsible for coagulation are dimeric cationic proteins with molecular weight of 13,000 Da and isoelectric points between 10 and 11 (Jahn, 1981 and Ndabigengesere et al., 1995). The mechanism of coagulation was suggested to be adsorption and neutralisation of charges, or adsorption and bridging of destabilised particles, the two assumed to take place simultaneously. Gassenschmidt et al., (1995) reported the isolation from $M$. oleifera of a flocculating protein of 60 residues with molecular mass of about $6.5 \mathrm{kDa}$, isoelectronic point above $\mathrm{pH} 10$, high levels of glutamine, arginine and proline with the amino terminus blocked by pyroglutamate, and flocculant capacity comparable to a synthetic polyacrylamide cationic polymer. However, a non-protein coagulant has also been reported but not characterised (Okuda et al., 2001). Our earlier studies showed that M. oleifera seed powder is effective in heavy metal remediation of water (Sajidu et al., 2005). The African moringa, $M$. stenopetala is a quick growing tree $6-10 \mathrm{~m}$ tall with a trunk $60 \mathrm{~cm}$ in diameter at breast height, strongly branched, thick at base with a bark white to pale grey or silvery, smooth wood and soft leaves up to $55 \mathrm{~cm}$ long (Jahn, 1991 and Moges, 2004). The species is known by different vernacular names such as Kallanki and Haleko (Ethiopia), and Cabbage Tree (English). $M$. stenopetala is less widely distributed than $M$. oleifera but stenopetala is reportedly more resistant to insect pests than other members of the family and its seeds are larger and easier to process than those of oleifera (Kayambazinthu, 2003). Although the water clarifying properties of $M$. stenopetala have not been as extensively studied as those of M. oleifera, Jahn (1986) reported that $100-150 \mathrm{mg} / \mathrm{L}$ of $M$. stenopetala was as effective in water clarification as $200 \mathrm{mg} / \mathrm{L}$ of $M$. oleifera which indicates that stenopetala is more effective than oleifera. However, no work has been reported previously on the potential of $M$. stenopetala to remove heavy metals from water. The objectives of this study, therefore, were to evaluate the potential of $M$. stenopetala in removing lead from water and compare its effectiveness with that of $M$. oleifera reported earlier by our group (Sajidu et al., 2005) and therefore this is the first report on the potential of Moringa stenopetala on heavy metal removal.

\section{MATERIALS AND METHODS}

Seeds were identified by the Forestry Research Institute of Malawi. Moringa stenopetala seeds were obtained from Kenya (Whizpop Products Ltd., Nairobi) 
in 2005. Moringa oleifera seeds were collected from Chikwawa district in southern Malawi in 2004 and 2005. Seeds were deshelled by hand and the deshelled seeds were ground in a coffee mill (National MX-J210PN), until a consistent powder was obtained. Defatted cakes were prepared by cold solvent extraction of the powdered seed with hexane fraction and traces of fat were removed from the residue by washing with diethyl ether until the residue was confirmed as fat free using a paper test and then dried in a vacuum oven (Gallenkamp OVL $570010 \mathrm{~J}$ ) at 40 ÚC and 600 mbars for 24-48 h. The following analytical grade chemicals were used: lead nitrate (BDH Chemicals Limited, Poole, UK); sodium carbonate, magnesium sulphate, sodium bicarbonate, hexane fraction (Sarchem (Pty) Krugersdorp Ltd, RSA); sodium chloride, sodium hydroxide, calcium chloride and nitric acid (Associated Chemical Enterprises (Pty) Ltd, RSA); hydrochloric acid, diethyl ether (Glassworld, RSA). pH was determined using a pH meter (Metrohm 744) checked with buffers at $\mathrm{pH} 4$ and 7; constant temperature treatments were done in a constant temperature water bath (Bath: Haake Type 000-5584, Thermostirrer: Gallenkamp No. 85) and shaking was done using a Griffin shaker. Microsoft Excel was used for descriptive statistics and plots of treatment data. Analyses of variance were carried out using GenStat Discovery Edition.

\section{Synthetic lead water}

Synthetic lead water was obtained by dilution of a stock lead solution (1000 ppm) prepared by dissolving lead nitrate in de-ionised water or sodium chloride solution as described by the American Public Health Association (APHA, 1990).

\section{Determination of lead content}

Lead concentration was determined using atomic absorption spectroscopy (Shimadzu AA-680G V-5) at $283.3 \mathrm{~nm}$ with an air-acetylene flame as described by APHA (1990).

\section{Lead removal}

$100 \mathrm{~mL}$ of synthetic lead water containing $7 \mathrm{ppm}$ $\mathrm{Pb}$ was prepared using deionised water and appropriate masses of whole seed or defatted powder were added and the mixture stirred for $1 \mathrm{~h}$. The mixture was filtered by gravity through Whatman No.1 filter paper and the lead concentration of the filtrate was determined.
Kinetics of lead removal

Synthetic lead water containing $7 \mathrm{ppm} \mathrm{Pb}$ was treated with $1.0 \mathrm{~g}$ of Moringa oleifera and $0.5 \mathrm{~g}$ of Moringa stenopetala whole seed cake and the residual $\mathrm{Pb}$ concentration of the solution quantified after different times of treatment.

\section{Temperature dependence}

$7 \mathrm{ppm}$ synthetic lead water was treated with $1.0 \mathrm{~g}$ M. oleifera or stenopetala at different temperatures. The moringa suspension was immersed in a constant temperature water bath with shaking for $1 \mathrm{~h}$. and the residual lead concentration quantified.

\section{pH changes during treatment}

$2.5 \mathrm{~g}$ portions of $M$. stenopetala or oleifera were added to $100 \mathrm{ml}$ of $7 \mathrm{ppm}$ or $3 \mathrm{ppm} \mathrm{Pb}$ in deionised water or $0.1 \mathrm{M}$ sodium chloride and the $\mathrm{pH}$ recorded at intervals.

\section{Effect of pH on lead removal capacity}

Synthetic lead water of different $\mathrm{pH}$ 's were prepared by adjusting the $\mathrm{pH}$ of a solution of $7 \mathrm{ppm} \mathrm{Pb}$ in deionised water using $1 \mathrm{M}$ sodium hydroxide or hydrochloric acid and the resulting lead solutions treated with moringa whole seed cakes for $1 \mathrm{~h}$.

\section{Effect of water hardness}

$7 \mathrm{ppm}$ Pb solutions were treated with $1.5 \mathrm{~g}$ of moringa whole seed powders suspended in different concentrations of $\mathrm{Mg}^{2+} / \mathrm{Ca}^{2+}$ or $\mathrm{HCO}_{3}{ }^{-} / \mathrm{CO}_{3}{ }^{2-}$ mixtures. The $\mathrm{Mg}^{2+} / \mathrm{Ca}^{2+}$ was prepared as described in Texas specification No. 485-54-09A. The $\mathrm{HCO}_{3}-\mathrm{CO}_{3}{ }^{2}$ mixture was prepared by dissolving $1.3768 \mathrm{~g} \mathrm{NaHCO}_{3}$, and $1.7662 \mathrm{~g} \mathrm{Na}_{2} \mathrm{CO}_{3}$ to make a $1000 \mathrm{ppm}$ mixture and this was diluted to different appropriate concentrations.

\section{Effect of sodium chloride}

Solutions containing 7 ppm $\mathrm{Pb}$ in 0.0, 0.2, 0.4, 0.6, and $0.8 \mathrm{M}$ sodium chloride were prepared by combining and diluting the stock lead solution (1000 ppm) and a $1 \mathrm{M}$ stock solution of sodium chloride. The solutions were treated with $1.5 \mathrm{~g}$ of $M$. oleifera or stenopetala whole seed cake and the residual lead concentration determined.

\section{RESULTS}

\section{Lead ion removal}

Lead treatment was done using different doses of moringa whole seed powder. The results indicate that $M$. stenopetala has the capacity to remove heavy metals 
from water (Table 1) and the effectiveness of removal increased with increasing dosage of whole seed powder with $\mathrm{p}<0.001$ at $95 \% \mathrm{CL}$. There was no significant difference for lead removal at $1 \mathrm{~h}$ and $24 \mathrm{~h}$. $(\mathrm{p}=0.348)$. Similar results were obtained using defatted cakes (Table 2). Metal ion removal increased with increasing dosage of $M$. stenopetala defatted seed cake $(\mathrm{p}<0.001)$ and there was no significant difference for $\mathrm{Pb}$ removal at $1 \mathrm{~h}$. and 24 h. $(p=0.55)$. The effectiveness of $\mathrm{Pb}$ removal of the defatted cakes (Table 2) and the whole seed powder (Table 1) was also compared and the defatted cakes were more effective than the whole seed cakes ( $\mathrm{p}<0.001$ ). Comparison of the removal effectiveness of Moringa oleifera and Moringa stenopetala (Table 3) using ANOVA showed that there was a significant difference in the effectiveness of removal with stenopetala being more effective than oleifera $(\mathrm{p}=$ 0.001).

\section{Kinetics of lead removal}

Time dependence studies of lead removal by stenopetala gave a straight line plot for lead concentration versus time suggesting that removal is zero order with respect to metal ion (Fig. 1). For oleifera, a plot of natural log of lead concentration versus time gave a straight line indicating that removal is either first order or pseudo first order (Fig. 2).

\section{Effects of other ions on metal removal \\ (a) Sodium chloride}

Fig. 3 shows the effect of increasing $\mathrm{NaCl}$ ionic strength on lead removal using Moringa. Metal ion removal decreased with an increase in the concentration of $\mathrm{NaCl}$ from 0.0 to $0.8 \mathrm{M}$. The percentage decreased from 72.00 to $16.44 \%$ for oleifera and from 65.76 to $34.84 \%$ for stenopetala.

Table 1: Metal ion removal by M. stenopetala whole seed cake at initial metal ion concentration of 7 ppm at around 25 ÚC

\begin{tabular}{ccc}
\hline Dosage (g/100 mL) & $\begin{array}{c}\text { Remaining lead conc./ppm } \\
\text { after 1 h. (\% removal) }\end{array}$ & $\begin{array}{c}\text { Remaining lead conc./ppm } \\
\text { after 24 h. (\% removal) }\end{array}$ \\
\hline \multirow{2}{*}{0.5} & $5.60 \pm 0.00$ & $5.03 \pm 0.25$ \\
& $(20.00 \pm 0.00)$ & $(28.14 \pm 3.57)$ \\
1.0 & $3.77 \pm 0.14$ & $3.28 \pm 0.00$ \\
& $(46.19 \pm 2.06)$ & $(53.14 \pm 0.00)$ \\
1.5 & $2.02 \pm 0.14$ & $2.03 \pm 0.00$ \\
& $(71.19 \pm 2.06)$ & $(71.00 \pm 0.00)$ \\
2.0 & $0.74 \pm 0.04$ & $(85.85 \pm 0.004$ \\
2.5 & $(89.43 \pm 0.60)$ & $0.71 \pm 0.03$ \\
& $0.26 \pm 0.01$ & $(89.83 \pm 0.46)$ \\
\hline
\end{tabular}

Table 2: Metal ion removal by hexane defatted M. stenopetala at initial metal ion concentration of 7 ppm around 25 ÚC

\begin{tabular}{ccc}
\hline $\begin{array}{c}\text { Dosage } \\
(\mathrm{g} / 100 \mathrm{~mL})\end{array}$ & $\begin{array}{c}\text { Remaining lead conc./ppm } \\
\text { after 1 h. (\% removal) }\end{array}$ & $\begin{array}{c}\text { Remaining lead conc./ppm } \\
\text { after 24 h. (\% removal) }\end{array}$ \\
\hline 0.5 & $4.43 \pm 0.27$ & $4.35 \pm 0.00$ \\
1.0 & $(36.76 \pm 3.79)$ & $(38.000 .00)$ \\
1.5 & $1.640 .13(76.71 \pm 1.98)$ & $1.87 \pm 0.13(73.33 \pm 1.88)$ \\
2.5 & Not detected & Not detected \\
\hline
\end{tabular}

Table 3: Comparison of $1 \mathrm{~h}$. treatment of lead water using whole seed powders M. oleifera and M. stenopetala

\begin{tabular}{ccc}
\hline $\begin{array}{c}\text { Dosage } \\
(\mathrm{g} / 100 \mathrm{~mL})\end{array}$ & $\begin{array}{c}\text { Remaining lead conc./ppm } \\
\text { MOWSK (\% removal) }\end{array}$ & $\begin{array}{c}\text { Remaining lead conc./ppm } \\
\text { MSWSK (\% removal) }\end{array}$ \\
\hline \multirow{2}{*}{1.0} & $3.66 \pm 0.00$ & $3.36 \pm 0.17$ \\
& $(47.71 \pm 0.00)$ & $(52.05 \pm 2.40)$ \\
\multirow{2}{*}{1.5} & $2.21 \pm 0.00$ & $1.91 \pm 0.064$ \\
& $(68.43 \pm 0.00)$ & $(72.52 \pm 0.91)$ \\
\hline
\end{tabular}


Lead remediation of contaminated...

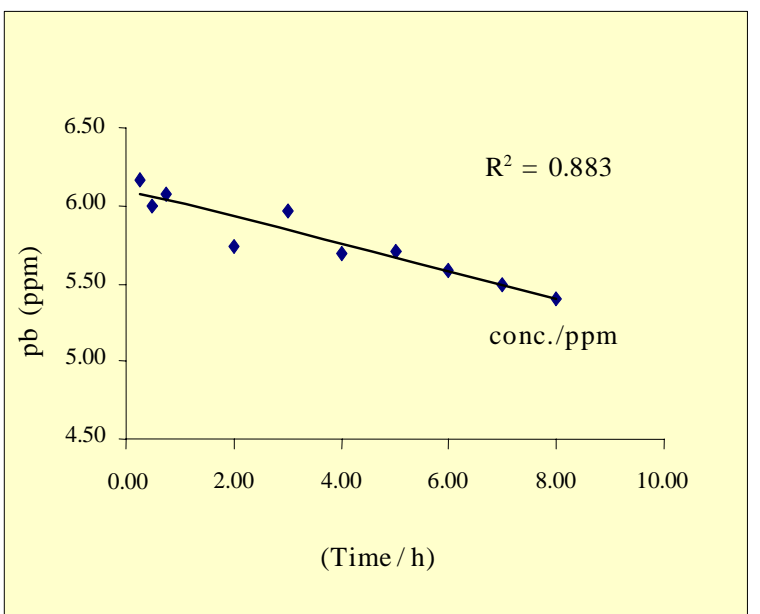

Fig. 1: Relationship between concentration and time for M. stenopetala whole seed cake

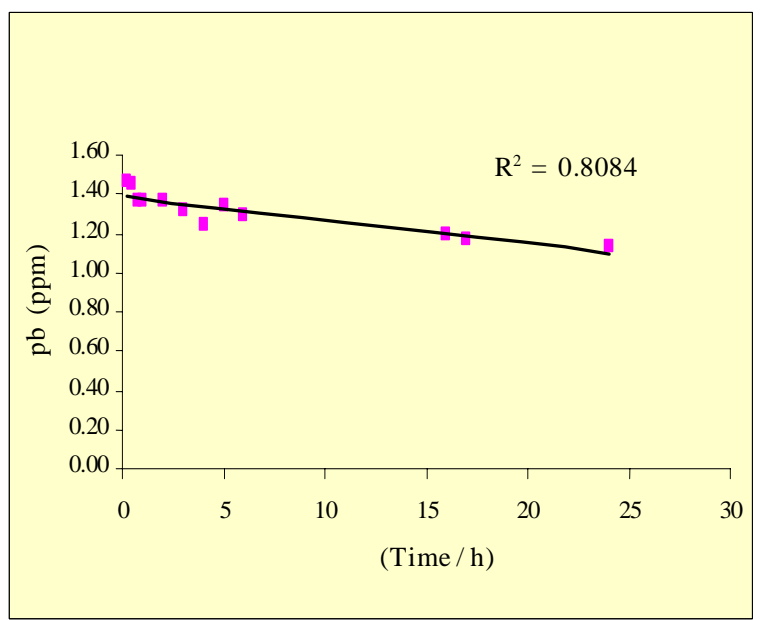

Fig. 2: Relationship between concentration and time for M. oleifera whole seed cake

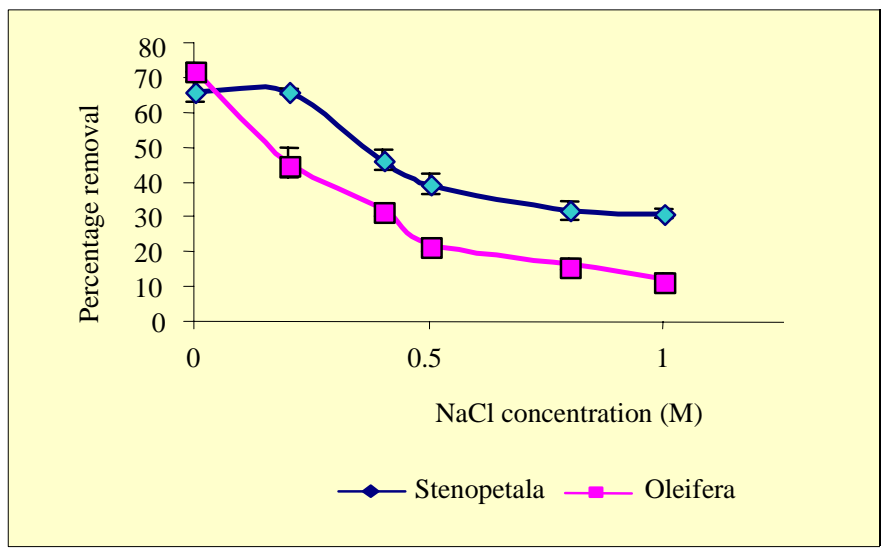

Fig. 3: Relationship between $\mathrm{NaCl}$ concentration and lead ion removal using Moringa whole seed cakes at initial lead ion concentration of $7 \mathrm{ppm}$

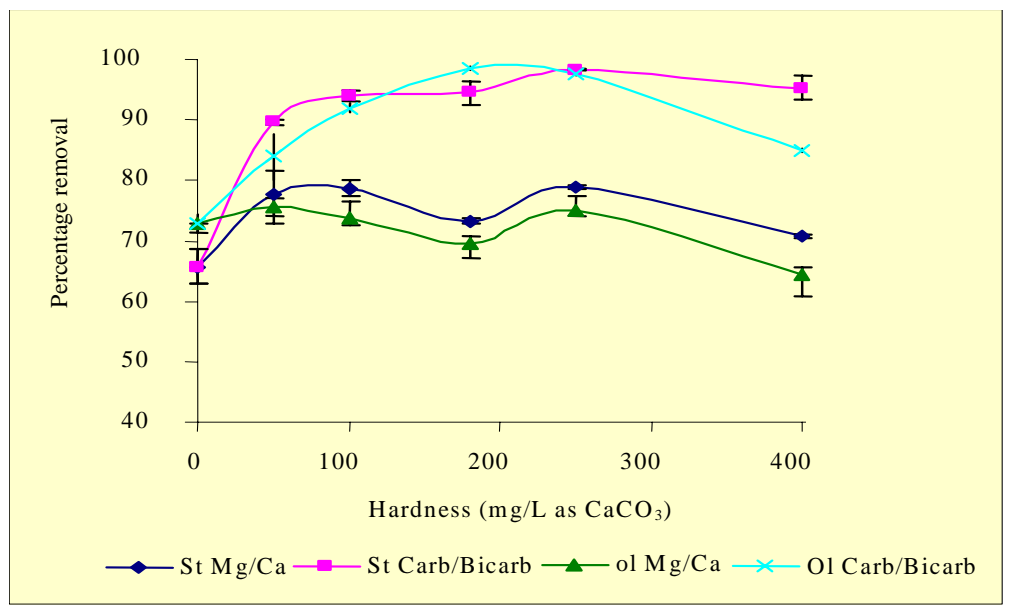

Fig. 4: Effects of water hardness on lead ion removal using oleifera and stenopetala whole seed cake at $7 \mathrm{ppm}$ lead concentration and $25{ }^{\circ} \mathrm{C}$ 
L. M. Mataka, et al.

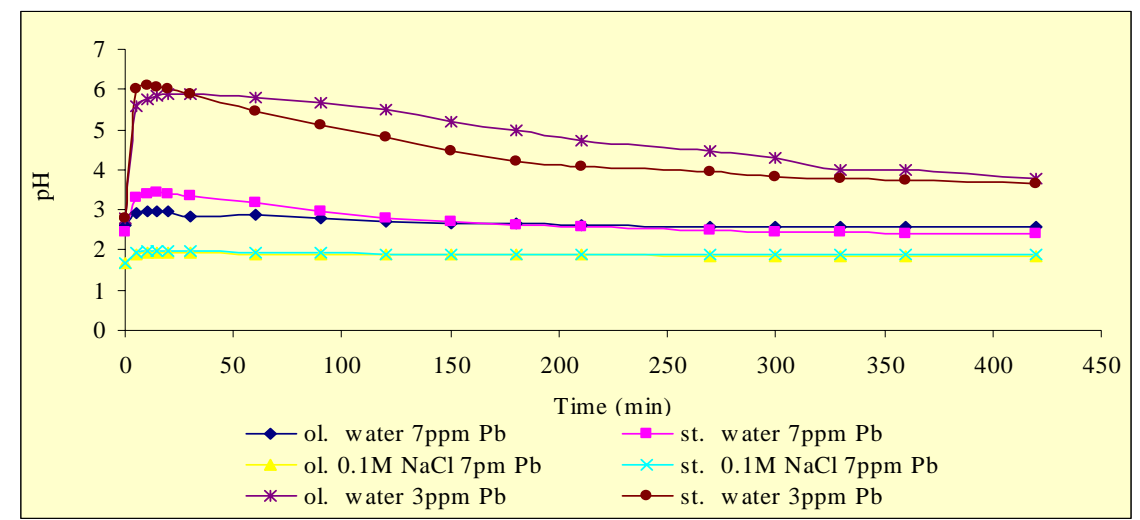

Fig. 5: Change in $\mathrm{pH}$ with treatment time for lead ion removal using $2.5 \mathrm{~g} M$. stenopetala and oleifera in de-ionised water and $0.1 \mathrm{M} \mathrm{NaCl}$ solution initial lead concentrations of 7 and 3 ppm (23.5 ÚC)

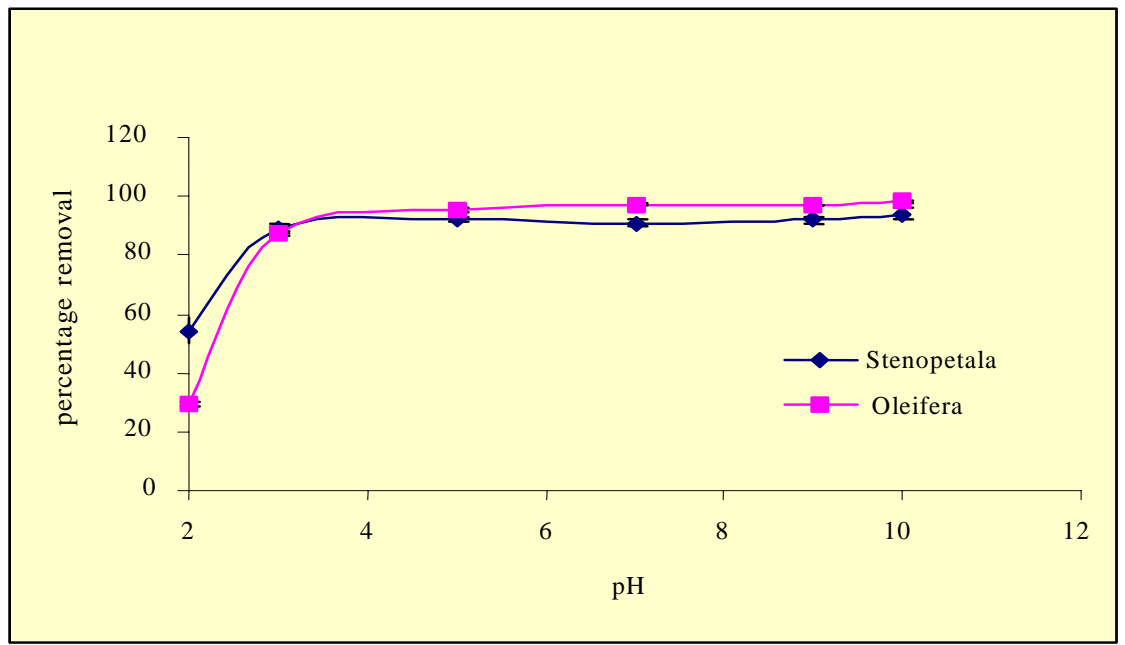

Fig. 6: Relationship between $\mathrm{pH}$ and percentage lead removal using Moringa whole seed cakes at initial lead ion concentration of $7 \mathrm{ppm}$ and $25{ }^{\circ} \mathrm{C}$

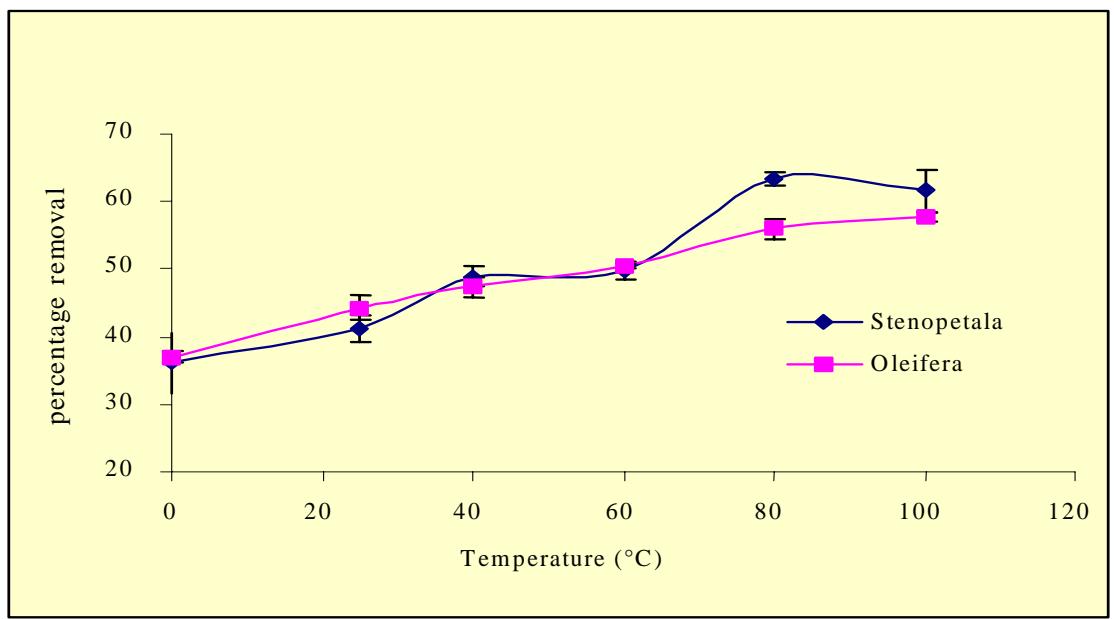

Fig. 7: The effects of temperature on lead removal using moringa seed powders at $7 \mathrm{ppm}$ initial lead concentration 
(b) Water hardness ions $\left(\mathrm{Mg}^{2+} / \mathrm{Ca}^{2+}\right.$ and $\left.\mathrm{HCO}_{3}{ }^{-} / \mathrm{CO}_{3}{ }^{2-}\right)$

Removal of lead ions in different concentration of magnesium/calcium or carbonate/bicarbonate mixtures was carried out to investigate the effects of increasing water hardness on the metal ions removal (Fig. 4). Percentage removal increased with the increase in carbonates/bicarbonates concentration and there was no general trend for magnesium/calcium.

\section{pH changes}

(a) $\mathrm{pH}$ changes in during treatment

Lead treatment was carried out in deionised water or $0.1 \mathrm{M}$ sodium chloride solution while recording $\mathrm{pH}$ at different time intervals to investigate the effects of treatment time on $\mathrm{pH}$ of the mixture(Fig. 5). The removal was done for different initial lead concentration of 3 ppm for deionised water and 7 ppm for both deionised and salt water. The variation in $\mathrm{pH}$ was more

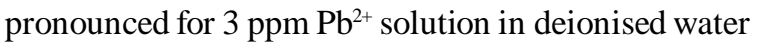
and least pronounced in $0.1 \mathrm{M} \mathrm{NaCl}$ solution.

\section{(b) Effect of initial $\mathrm{pH}$}

Treatment was carried out at different initial $\mathrm{pH}(\mathrm{pH}$ 2-10) to investigate the effects of initial $\mathrm{pH}$ on lead ions removal (Fig. 7). The percentage removal increased with an increase in initial $\mathrm{pH}$. The maximum removals for treatment with powders, $93.99 \%$ and $98.39 \%$, for oleifera and stenopetala respectively, were observed at $\mathrm{pH}$ 10. However significant change in percentage removal was observed between $\mathrm{pH} 2$ and 3 (29.21 87.42 and 54.31 - 89.07 for oleifera and stenopetala respectively).

\section{Effect of temperature on lead removal}

To investigate the effects of temperature on lead removal using $M$. oleifera and stenopetala whole seed powders lead treatment was done at different temperatures, 0, 25, 40, 60, 80, and $100{ }^{\circ} \mathrm{C}$ (Fig. 7). The percentage removal of lead ions increased with temperature from 36.69 to 57.76 and 36.07 to 61.57 for oleifera and stenopetala respectively.

\section{DISCUSSION AND CONCLUSION}

Our previous studies have shown that $M$. oleifera is effective in removal of heavy metals including lead from water (Sajidu et al., 2005). This present study indicates that $M$. stenopetala seed powders (whole seed and defatted seed) are more effective than oleifera in lead removal (Table 3). These results agree with
Jahn's (1986) observation that stenopetala is a better water clarifier than oleifera and suggests that the same agents, the polyelectrolytes, are responsible for water clarification and lead removal. Our observed increase in removal with increasing dosage of seed powders (Tables 1 and 2) is probably due to increasing concentration of the polyelectrolytes. Similarly the superiority of the defatted cake over whole seed cake may be due to the removal of lipids from the whole seed cake, thus increasing the relative concentration of the polyelectrolytes, the likely agents of metal ion removal. Increase in sodium chloride ionic strength caused a decrease in lead removal (Fig. 3) suggesting that the lead removal reaction involves electrostatic interaction (Krishnan and Anirudhan, 2003). At high ionic strength the sodium ions can compete for binding sites with $\mathrm{Pb}^{2+}$ ions on the polyelectrolytes and hence reduce lead removal. Furthermore $\mathrm{Pb}^{2+}$ ions form stable complexes with chloride ions, which inhibit interaction between $\mathrm{Pb}^{2+}$ and the polyelectrolyte sites. The effect of water hardness on lead removal varied depending on the ions involved (Fig. 4). Generally increase in concentration of carbonates/bicarbonates enhances lead removal; this effect can be explained by the formation of sparingly soluble lead carbonates that precipitate out of the solution (McGinnes, 2002). However there was no noticeable trend observed for the effect of the concentration of $\mathrm{Mg} / \mathrm{Ca}$ on lead removal and further studies are being carried out. For the variation in $\mathrm{pH}$ during the course of treatment (Fig. 5), there is a rapid increase in $\mathrm{pH}$ during the first few minutes as the seed powder dissolves to give free moringa polyelectrolyte in solution followed by a drop in $\mathrm{pH}$ as the dissolved polyelectrolyte interacts with the $\mathrm{Pb}^{2+}$ ions. The relative maximum $\mathrm{pH}$ values for the different treatments reflect the amount of free moringa polyelectrolyte in solution. Therefore at low concentration ( $3 \mathrm{ppm}$ ) of $\mathrm{Pb}^{2+}$ the highest concentration of free polyelectrolytes is expected due to less interaction between the sites leading to the highest maximum $\mathrm{pH}$. At $7 \mathrm{ppm}$ more interaction is expected due to a higher amount of $\mathrm{Pb}^{2+}$ hence the observed lower maximum $\mathrm{pH}$. The lowest maximum $\mathrm{pH}$ was obtained for the treatment in $0.1 \mathrm{M}$ sodium chloride solution and may be explained by the presence of a greater amount of metal ions which have a salting in effect on proteins and inhibit the extraction and dissolution of the free polyelectrolytes. The observed increase in lead ion removal with increase in initial $\mathrm{pH}$, 
may be attributed to the formation of insoluble lead hydroxides at higher $\mathrm{pH}$. The lower efficiency in lead removal at low $\mathrm{pH}$ probably may arise from the presence of a large amount of $\mathrm{H}^{+}$ions in the mixture, which compete with $\mathrm{Pb}^{2+}$ ions for the binding sites (Krishnan and Anirudhan, 2003 and Raji et al, 1997). The increase in lead ion removal with temperature is possibly due to the breakdown of the protein chain, at higher temperatures to expose more sites for binding with metal ions. In conclusion the study has shown that Moringa stenopetala seed powder can be used as an effective heavy metal purifier in water and that Moringa stenopetala is more effective than oleifera in heavy metal removal.

\section{ACKNOWLEDGEMENT}

The authors acknowledge the material support of the International Programme in Chemical Sciences (IPICS) through the University of Uppsala, Sweden, the technical advice of the Forestry Institute of Malawi and the use of the atomic absorption spectrophotometer of the Geological Survey Department, Zomba.

\section{REFERENCES}

Alloway, B. J. and Ayres, D. C., (1990). Chemical principles of environmental pollution. Chapman Hall: London.

Anonymous, (1990). APHA. Standard methods for the examination of wastewater, $17^{\text {th. }}$ Ed.. Washington DC.

Anonymous, (2004). UNEP. Water Policy and Strategy. United Nations Environment Programme http:/www.unep.org. 14/ 09/05.

Anonymous, (2004). World Health Organisation (WHO). Guidelines for drinking water quality Vol 1. Recommendations, WHO: Geneva.

Banda, L., Fabiano, E. and Saka, J. D. K., (2001). Effects of human activities on water quality in Lunyangwa River basin, Mzuzu, Malawi. Proceedings of the First Chancellor College Research Dissemination Conference. 28-30 March 2001. University of Malawi. Zomba, 274-275.

Coote, C., Bonongwe, C. and Stewart, M., (1997). The distribution, uses and potential of development of Moringa oleifera in Malawi. Forestry Research Record Forest Research Institute of Malawi, Zomba, 67.

Evans, C. V., (2003). Removal of heavy metals and radionuclides from soils using cationic surfactant flushing. University of Wisconsin Water Resources Institute.

Fatoki, O. S. and Ogunfowokan, A. O., (2002). Effect of coagulant treatment on the metal composition of raw water. Water SA., 28 (3).

Gassenschmidt, U., Jany, D. K. and Tauscher, N. H., (1994). Isolation and characterisation of a flocculating protein from Moringa oleifera Lam. Biochemica et Biophysica Acta 1243, 477-481.

Ghebremichael, K. A., (2004). Moringa seed and pumice as alternative natural materials for drinking water treatment. Ph.D., Thesis. University of Stockholm, Sweden.
Henry, E., Dembo, E. G., Sajidu, S. M. and Zimba, G., (2005). A Preliminary Investigation on use of Moringa oleifera polyelectrolytes for wastewater treatment in Malawi. $283-$ 291. In: K. Mathew, I. Nhapi (Eds.). Water \& wastewater management for developing countries (WAMDEC 2004). IWA Water and Environment Management Series ISB \#184339-511-8 Proceedings of the Water \& Wastewater Management for Developing Countries Conference, Victoria Falls, 28- 30.

Jahn, S. A., (1981). Tradition water purification in tropical and developing countries Existing methods and potential application. Publ 117. Deutsche Gesellschaft fur Technische Zusammenarbeit (GTZ) GmbH, Eschborn.

Jahn, S. A., (1986). Proper use of African natural coagulants for rural water supplies: Research in the Sudan and a guide for new projects. Deutsche Gesellschaft fur Technische Zusammenarbeit (GTZ) GmbH, Eschborn.

Jahn, S. A., (1991). The Traditional Domestication of a multipurpose tree Moringa stenopetala (Bak. f.) Cuf. In the Ethiopian Rift Valley. Ambio., 20, 244-247.

Krishnan, K. A. and Anirudhan, T. S., (2003). Removal of cadmium (II) from aqueous solutions by steam-activated sulphurised carbon prepared from sugar-cane bagasse pith: Kinetics and equilibrium studies. Water SA., 29, 147-156.

Lambert, M., Leven, B. and Green, R., (2003). New methods of cleaning up heavy metal in soils and water innovative solutions to an environmental problem http:// www.envirotools.org/ 17/07/05.

Lyte, C. M., Lytle, W. F., Yang, N., Quian, J., Hansen, B., Zayed, A. and Terry, N., (1998). Reduction of Cr (IV) to $\mathrm{Cr}$ (III) by wetland plants: Potential for situ heavy metal detoxification. Environ. Sci. Tech., 32, 3087-3093

Malawi Government, (2002). State of Environmental Report for Malawi 2002. Ministry of Natural resources and Environmental Affairs, Lilongwe, Malawi.

Matope J., (2002). Blantyre City Environment Profile Report, United Nations Development Programme: Geneva.

McGinnes, M., (2002). Wastewater from a Lead-Acid battery washing operation. Ecoshield Environmental Systems, Inc. www.nmfrc.org. 30/08/05.

Moges, Y., (2004). Recommended agroforestry/multipurpose trees for Borana lowlands/midlands and their production techniques. Subreport No.4: FARM Africa/SOS Sahel, Tropical forestry.

Morton, J. F., (1991). The Horseradish tree, Moringa Pterygosperma (Moringacae) - A Boon to Arid Lands. Economic Botany, 45, 318-333.

Ndabigengesere, A., Narasiah, K. S. and Talbot, G. B., (1995). Active agents and mechanism of coagulation of turbid waters using Moringa oleifera. Water Res., 29, 703-710.

Okuda, T., Baes, A. U., Nishijima, W. and Okada, M., (2001). Coagulation mechanism of salt solution extracted active component in Moringa oleifera seed. Water Res., 35 (3), 830-834.

Palgrave, K. C., (1983). Trees of southern Africa. Struik Publishers (Pty), Capetown.

Raji, C., Manju, G. N. and Anirudhan, T. S., (1997). Removal of heavy metal ions from water using sawdust-based activated carbon. Indian J. Eng. Mater. Sci., 4, 228-236.

Sajidu, S. M. I., Henry, E. M. T., Kwamdera, G. and Mataka, L., (2005). Removal of lead, iron and cadmium by means of 
polyelectrolytes from Moringa oleifera whole seed kernel: Water Resource Management III, 251.

Singh, S. P., Ma, L. Q. and Harris, W. G., (2001). Heavy metal interactions with phosphatic clay: sorption and desorption behaviour. J. Environ. Qual., 30, 1961-1968.

Sutherland, J. P., Folkard, G. K., Mtawali, M. A. and Grant, W. D., (1994). Moringa oleifera as a natural coagulant. 20 $0^{\text {th. }}$ Water Engineering and Development Centre (WEDC) Conference held in Colombo, Sri Lanka.
Texas Specification (1996). Specification for floor finish remover concentrate http://www.tbpc.state.tx.us. No. 48554-09A. 15/08/05.

Van Wyk, B. and Van Wyk, P., (1998). Field guide to trees of southern Africa Struik Publishers (Pty), Capetown 8001.

Williamson, J., (1975). Useful plants of Malawi. University of Malawi. Zomba.

\section{AUTHOR(S) BIOSKETCHES}

Mataka, L. M., BEd., is a lecturer in the Department of Chemistry, Domasi College of Education and an M.Sc. research student in environmental chemistry at the Chemistry Department, Chancellor College, University of Malawi, Zomba, Malawi. E-mail: Imataka@yahoo.com

Henry, E. M. T., Ph.D., is a professor in the School of Science, University of Fort Hare, South Africa and also adjunct in the Department of Chemistry, Chancellor College, University of Malawi.

E-mail: ehenry@ufh.ac.za

Masamba, W. R. L., Ph.D., is an associate professor in the Department of Chemistry, Chancellor College, University of Malawi currently on leave of absence at the University of Botswana.

E-mail:wmasamba@orc.ub.bw

Sajidu, S. M., M.Sc., is a lecturer in the Department of Chemistry, Chancellor College, University of Malawi and Ph.D. research student in environmental chemistry at the Chemistry Department, Chancellor College, University of Malawi, Zomba, Malawi. E-mail: ssajidu@yahoo.co.uk

\section{This article should be referenced as follows:}

Mataka, L. M., Henry, E. M. T., Masamba, W. R. L. and Sajidu, S. M., (2006). Lead remediation of contaminated water using Moringa Stenopetala and Moringa oleifera seed powder. Int. J. Environ. Sci. Tech., 3 (2), 131-139. 